\title{
Performance Appraisal Strategies on Performance of Teachers in Public Secondary Schools in Kiambu County, Kenya
}

\author{
Bernadette Wangui Mwangi ${ }^{1}$ and Reuben Njuguna, $\mathbf{P h} . \mathrm{D}^{\mathbf{2}}$ \\ ${ }^{1}$ Correspondent Author, School of Business, Kenyatta University, Kenya \\ ${ }^{2}$ Department of Business Administration, School of Business, Kenyatta University, Kenya \\ ABSTRACT
}

This study was triggered by the Teachers Sercice Commission (TSC) coming up with teachers performance appraisal strategies to appraise teachers and administrators in its employment, but the program has not fully realized the objective of evaluating teachers performance and initiate professional development. There has been a stiff resistance from teachers on the use of appraisal tool terming it as forced appraisal. The study, therefore, sought to establish whether there is a relationship between appraisal and reward/compensation, examine how setting of standards and targets influences teachers perfomance, determine how measuring and monitoring teachers work on regular basis affect their performance and find out the effect of quality of work on performance of teachers in public secondary schools in Kiambu County. The target population was 3,479 teachers in 277 public secondary schools in Kiambu County. The study was conducted in 22 secondary schools in 11 sub counties comprising TSC teachers and administrators with a population of 686. 58 teachers and 22 head teachers, totaling to 80 representing $12 \%$ were selected from the accessible population of 686 teachers using systematic random sampling. The study established that standards/targets, measuring and monitoring performance managing quality of work and reward/pay affects teacher performance positively and significantly. The study concludes that setting standards and target allows schools and the teaching staff to better measure their progress helping to keep them motivated and accountable. Measuring and monitoring teacher performance ensures that information is gathered so that judgments can be made and questions answered accordingly. Performance appraisal strategies are critical to satisfying the performance of teacher and retaining their future loyalty and teachers are satisfied with the extrinsic rewards provided from the organization like: pay, bonuses, allowances. The study recommends that for the management of schools to achieve goal alignment in the teaching staff, they must first clearly communicate their school's strategic objectives across the entire school. The school should have a way of monitoring their teacher which must be developed in a systematic monitoring and evaluation of the class and the work of teachers. On managing the quality of work, the study recommends that schools match tasks to Skills, communicate effectively, keep goals clear \& focused, give incentives, train and develop their teachers and the study recommends that the school management should take interest in the professional growth to increase the performance level of the teachers.

Key Words: Performance Appraisal, Human Resource Strategies, Teachers Performance, Public Secondary Schools 
DOI: 10.7176/ijcab.v3iII.1, URN urn:nbn:de:0000ijcab.v3iII.196

\section{Cite this Article:}

Mwangi, B., \& Njuguna, R. (2019). Performance Appraisal Strategies on Performance of Teachers in Public Secondary Schools in Kiambu County, Kenya. International Journal of Current Aspects, 3(II), 218-230. http://journals.ijcab.org/journals/index.php/ijcab/article/view/19

\section{INTRODUCTION}

Performance appraisal continues to be one of the most important functions of human resource management in the $21^{\text {st }}$ Century. This is because performance of workers or employees is critical to the effectiveness and competitiveness of an organization. Armstrong (2014) portrays the job of performance appraisal as an instrument for checking what should be finished by individuals in an association for it to accomplish the motivation behind the activity to address new difficulties. In the firm's setting, performance appraisal is a methodical assessment of staff by their seniors or others comfortable with their execution. An appraisal system is a critical device that can be utilized to enhance the nature of organization's employeee performance which accupty a critical management of of human resources as well as one of management functions. For the organization to be able to accomplish its goals, arranging of the evaluation procedure assumes a critical job in representatives advancement, including advancements and taking administrative work, compensation alterations, influence and discipline, staff input and deciding needs for training (Mwema and Gachunga, 2014). Performance appraisal need to be considered to be an essential factor in recognizing the general population's gifts and limits and the input cam make them mindful of the advancement, plans and objectives.

According to Cole (2009) performance appraisal is done inside a practically which is basically the everyday business of the venture. What is being surveyed in the principal occurrence is the performance of an employee in doing the general obligations of his or her job, together with some particular focuses on that have been set. Also, the evaluation might be utilized to survey an individual appropriateness for advancement, either for the most part or considering a particular occupation. In the appraisal processes, people are qualified to solicit viewpoints from their activity in which they are being surveyed and against certain criteria. The framework for a performance appraisal is a decent instrument that can be utilized to enhance the nature of an organization's work constrain execution of which it is considered as an essential perspective in HR administration and as a feature of the control procedure in organization. All together for an organization to accomplish its targets, arranging of the evaluation procedure is a vital subject which ought to be embraced to empower it accomplishes the goals like work constrain advancement, including changes, advancements and assignments in administrative positions, influence and discipline, pay increment, staff's execution criticism and deciding their career development needs (Mwema and Gachunga, 2014). 
Performance appraisal is the procedure by which a supervisor or expert analyzes and assesses the employee's work conduct by contrasting it with preset measures, reports the consequences of the correlation and utilizations the outcomes to give criticism to the worker to demonstrate where upgrades are required and why. They are additionally significant execution administration apparatus to assess the performance and what an employee give and set objectives for the following survey time frame (Cole, 2009). Teacher assessment is regularizing in nature on the grounds that an esteem judgment is given. This esteem judgment must be weighed against unequivocal criteria of reasonableness and ought to dependably satisfy a specific capacity. Teacher assessment satisfies two principle works to be specific; a developmental capacity for the advancement of expert showing required skills. Performance appraisal should be directed routinely to survey a representative execution estimated against the activity's expressed or expected prerequisites. Employees need to be mindful of what is anticipated from them, and the measuring standards by which their performance and results will be estimated. Laurie J. Mullins as cited substantiated the need of a compelling performance appraisal by saying that it can recognize a person's qualities and shortcomings and demonstrate how such qualities may best be used and shortcomings be addressed. The performance appraisal ought to be utilized in settling on choices on compensation and wage builds, exchanges, advancements and expulsions and also conveying data to the assesses on their advancement. The appraisal results are used to talk about and advancement of a worker in connection to the objectives set (Mwema and Gachunga, 2014).

The Teachers Service Commission is commanded to undertake the performance and conduct of teacher in the teaching service. In such manner, the Commission presented an open Performance Appraisal System for teachers to fortify supervision and to ceaselessly screen their performance in educational curriculum usage at the institutional level. The evaluation framework is utilized to give criticism, enhance correspondence, and illuminate jobs and obligations. As stipulated in Section 52 of the Code of Regulations for Teachers (2015), the Commission will in directing the performance examination framework; Requires heads of organization to give oversight job in the performance evaluation for the teachers in their particular establishments, utilize performance appraisal reports for reasons for advancement, arrangement and different rewards as might be recommended, Identify preparing necessities and take remedial measures in instances of inadmissible performance and create and audit criteria, rules and devices for performance appraisal.

The term employee performance is person's work accomplishment in the wake of putting the required exertion at work and which is related however getting an important work, connecting with others and empathetic partners (Pradham and Jenn, 2016). Performance of employees in an organization is a key worry of directors regardless of their level and position. Individual employee behavior on self-control and achievement of organizational goals form an important part of employee performance. Job performance involves both the quality and quality of work performed and this is important in evaluating performance of employees. Performance also involves efficiency, which refers to the rate of output on job execution and also being able to meet the given deadlines. Effectiveness in performance means the employees is able to do the job right. Efficacy which represents the goal accomplishment rate of work by an employee is also important (Dhammika, 2016). 
Management control which is an efficient push to set performance models with arranging destinations, outlining data input frameworks, contrasting the real performance and these foreordained gauges to decide if they are any deviations and to quantify their noteworthiness and to make suitable move that shape an essential part of performance (Robbins and Coulter, 2010).

In the late 20th century, an awesome change in ways to deal with execution evaluation frameworks over the world was seen. There has been an incredible acknowledgment that it is more imperative to center around characterizing, arranging and overseeing execution than simply assessing execution. Peformance appraisal is the conventional way to deal with assessing the execution of a representative. Numerous individuals imagine that performance appraisal is another name given to job evaluation and that there is no contrast between the two (Prasad 2005). Most organizations along these lines take performance appraisal to be synonymous with job evaluation. However it is unmistakably in excess of another name for performance appraisal Cole (2009). Teachers Service Commission is commanded to play out the accompanying capacities: enlist teachers who are trained; recruit and select appropriate teachers, appoint teachers utilized by the commission for benefit in any government funded school or organization, carry out promotions; practice disciplinary power over teachers; survey the benchmarks of training and preparing and improvement of teachers, audit the interest for and supply of teachers; and exhort the national government on issues identifying with the instructing calling (www.tsc.ac.ke).

The mission of TSC is to build up and keep up an adequate, proficient showing administration for instructive foundations. The basic beliefs; polished skill: All TSC workers will watch necessities for expert lead. The representatives are relied upon to apply the abilities, information, capabilities that satisfy the guidelines required for the work alloted. Client center: The Commission puts the client first by maintaining the theory of client drivenadministration conveyance. Representatives are relied upon to exhibit an abnormal state of responsiveness to client needs. Trustworthiness' representatives behave in a way that exhibits genuineness, high good and moral principles, and promise to work. This is in line to the goals of Part 6 of the Constitution, and the Implicit rules and Morals for Instructors. Creativity: representatives try to infuse new thoughts and methodologies in administration conveyance. Camaraderie: Commission representatives are focused on working through cross-status and cross useful groups. All representatives are prepared to deal with work connections and offer new data with associates (www.tsc.go.ke). The number of TSC employed teachers in Kiambu County is 3,479 teachers in 277 public schools spread throughout the County. Kiambu County will be considered because of accessibility. Considering the aspect of cost and time, 22 schools from 11 different sub counties were selected for this study.

\section{STATEMENT OF THE PROBLEM}

Performance appraisal is motivated by the organizations desire to change employee attitudes and behavior and ultimately performance. The appraisal will be effective if there are clear performance standards and targets and continuous measurement and monitoring of progress. Any variance is appropriately addressed and good performance is rewarded through added responsibilities, promotions or higher pay (Gachunga \& Mwema, 2014). The new teachers 
performance appraisal strategies has not achieved its expectations of improving teachers commitment to their work and quality education. KNUT and KUPPET (2018) have opposed the appraisal for being exclusive, process oriented and not teachers oriented, lengthy and tiring process that does not yield in terms of job improvement, promotion or transfer and salary review. Performance appraisal strategies for teahers has been found to be subjective on performance; no clear work planning; setting of targets that are not realistic; lack of feeding and generally there is little contribution from human resource management on recruitment, training and career progression (Mwema \& Gachunga, 2014). Teachers are not against performance appraisal, but fear being victimized by their employer, favouritism from appraisers, biasness and lack of feedback and their performance not being used for rewarding (KNUT Mid-tem Report (2016). Much of the previous studies have been focusing on the influence of performance appraisal on performance in the public service. Karimi (2013) carried out a study on the influence of performance appraisal on job performance in the public sector; Mwema and Gachunga (2014) carried out a study on the influences of performance appraisal on employees productivity in selected WHO offices in Kenya. There is no known research that have been carried out on performance appraisal strategies on teachers performance in public secondary schools in Kiambu County

\section{OBJECTIVES OF THE STUDY}

The general objective of the study was to investigate performance appraisal strategies on performance of teachers in public secondary schools in Kiambu County.

The specific objectives were:

i. To determine how setting standards influences teachers performance in public secondary schools in Kiambu County.

ii. To establish how managing the quality of work influences the performance of teachers in public secondary schools in Kiambu County.

iii. To assess the effects of measuring and monitoring performance on teachers performance in public secondary schools in Kiambu County.

iv. To examine the relationship between reward and appraisal on teachers performance in public secondary schools in Kiambu County.

\section{THEORETICAL FRAMEWORK}

The theoretical orientation in this chapter aimed to present a framework for understanding the performance appraisal in theoretical perspectives. Some of the theories on performance appraisal include goal setting theory, expectancy theory and equity theory.

\subsection{Goal Setting Theory}

Goal-setting theory was proposed by Edwin Locke in the year 1976. This theory proposes that individual objectives set up by an employee assume an essential job in spurring him/her for unrivaled performance. This is on the grounds that the employees continues following his/her objectives. In the event that these objectives are not accomplished, they either enhance their performance or alter the objectives and make them more reasonable. In the 
event that the performance enhances it will result in accomplishment of the performance appraisal framework points (Robbins \& Coulter, 2010). Defining objectives can help persuade a representative since it makes them feel required. This inclination can decipher in objective driven conduct that proceed until the worker never again feel required. The sort of objective can direct an employee's level of inspiration when he/she faces in excess of one goal. So also, an employee will build hi/her level of investment in defining an objective if the worker feels that the procedure incorporates reasonableness and self-rule (Robbins \& Coulter, 2010). Robbins and Coulter (2010) quoting Locke (1976) noted that the objective an individual is going for which propels, as opposed to only the fulfillment of accomplishing it. Locke's view is that what a man esteems or wants decides the objectives he sets for himself, yet that what really drives him (rouses him) are simply the objectives. When the goals are blocked the employees is demotivated. Locke's own researches indicated that individual performance was better when individuals had been define particular objectives of a testing or troublesome nature, and when they got input on their execution. This methodology obviously has suggestions for the act of administration by-destinations, or target setting, which depends for its prosperity on the common assention of particular objectives between a director and his subordinate (Cole, 2009). This is applicable in the relationship between the teacher and his/her supervisor.

\subsection{Expectancy Theory}

Expectancy theory was proposed by Victor Vroom in 1964. This theory depends on the hypothesis that people modify their conduct in the association based on foreseen fulfillment of esteemed objectives set by them. The people change their conduct in a way well on the way to lead them to accomplish these objectives. This hypothesis underlies the idea of execution examination as it is trusted that execution is affected by the desires concerning future occasions (Martin and Tourish, 2017). According to Robbins and Coulter (2010) expectancy theory states than an individual tends to act surely in view of desire that the demonstration will be trailed by a given result and the appeal of that result and on the engaging quality of that result to the person. It incorporates three factors, or connections: Expectancy, or exertion execution linkage, is the likelihood seen by a person that applying a given measure of exertion will prompt a specific level of execution; instrumentality, or execution compensate linkage, is how much an individual trusts that performing at a specific level is instrumental in accomplishing the coveted result; valence, or appeal of remuneration, is the significance than an individual places on the potential result or reward that can be accomplished at work. Valence considers both the goals and needs of the individual (Robbins and Coulter, 2010). Cole (2009) quoting Lawler (1971) noted that in thinking about remunerations, the fulfillment picked up by an individual is represented by the distinction between 'the measure of some esteemed result that a man gets and the measure of that result he believes he ought to get.' Moreover, the sum a man feels he ought to get (is) unequivocally impacted by what he sees others... are getting.' The suggestions for administration of these remarks are that organizations do need to give an arrangement of evenhanded installment for their workers. Notwithstanding any transactions with exchange associations, if administrations need a persuaded workforce, at that point they should guarantee that the 
prizes for exertion, different things being equivalent, are viewed as reasonable by all the employees.

\subsection{Agency Theory}

Agency theory explores how firms ensure that there is a relationship of interests between the principals (owners) and agents (employees). Individuals are propelled independent from anyone else intrigue, mostly or only as monetary computations that abrogate such issues as trust, steadfastness and fellowship systems. According to Evans and Tourish (2017) menager versus employee examination process remains a generally utilized system for the performance appraisal in the vast majority of the organizations. Performance appraisal brings a large number of advantages to both the organizations and the workers. The advantages incorporate the chance to guarantee that staff seek after objectives that are lined up with the more extensive hierarchical destinations set by senior supervisors; arrangement of target appraisal and customary input, which is expected will enhance learning; increased responsibility and inspiration; better vocation administration; better employee relations and enhanced connection between's the prizes/pay and management performance.

Incomprehensibly, execution evaluation has been noted to be a standout amongst the most diligent issues looked by both the supervisors and the workers. This worry returns very nearly sixty years, when McGregor (1957) had an article "An uneasy take a gander at execution evaluation." It is considered as a yearly custom and a few proposals made is that it should be annulled by and large. DiNisi et al, 2014 reasoned that there is in actuality no proof to associate individual examinations with firms enhancements in execution. Evans and Tourish (2017) identified many problems associated with how performance appraisal is implemented. Therefore, much research has focused on improving the process of performance appraisal. This has faced hurdles as as appraisers are depicted as suffering from biasness in their perceptions of others, lacking in feedback skills, poor at listening, too wedded or insufficiently wedded to appraisal forms and feedback that is too frequent or infrequent. The agency theory comes in handy to address the problems of performance appraisal. The fundamental focal point of HRM has been the means by which adequately ways to deal with individuals administration bolster the general business procedure of associations (Martin et al, 2016). At the point when those methodologies are commanded by office viewpoints and financial contemplations, HR practices, one of them being performance appraisal will come to share those impacts. There is likewise a presumption that whatever issues of estimation or assessment that emerge can be unraveled by more advanced philosophies. The issues of examination setting, power and control are ousted to the sidelines, while supervisors are coerced to enhance their systems for assessing execution, offering criticism and defining objectives.

\section{CONCEPTUAL FRAMEWORK}

Mugenda \& Mugenda (2013) defines conceptual framework as a concise description of the phenomenon under study accompanied by a graphical or visual depiction of the major variables of the study. A conceptual framework is a set of broad ideas and principles taken from relevant field of inquiry and used to structure a subsequent. When clearly articulated, a conceptual framework has potential usefulness as a tool to assist a researcher to make 
meaning of subsequent findings. It forms part of the agenda for negotiation to be scrutinized and tested, reviewed and reformed as a result of investigations (Guba and Lincoln, 1989).

\section{Independent Variables}

\section{Dependent Variable}

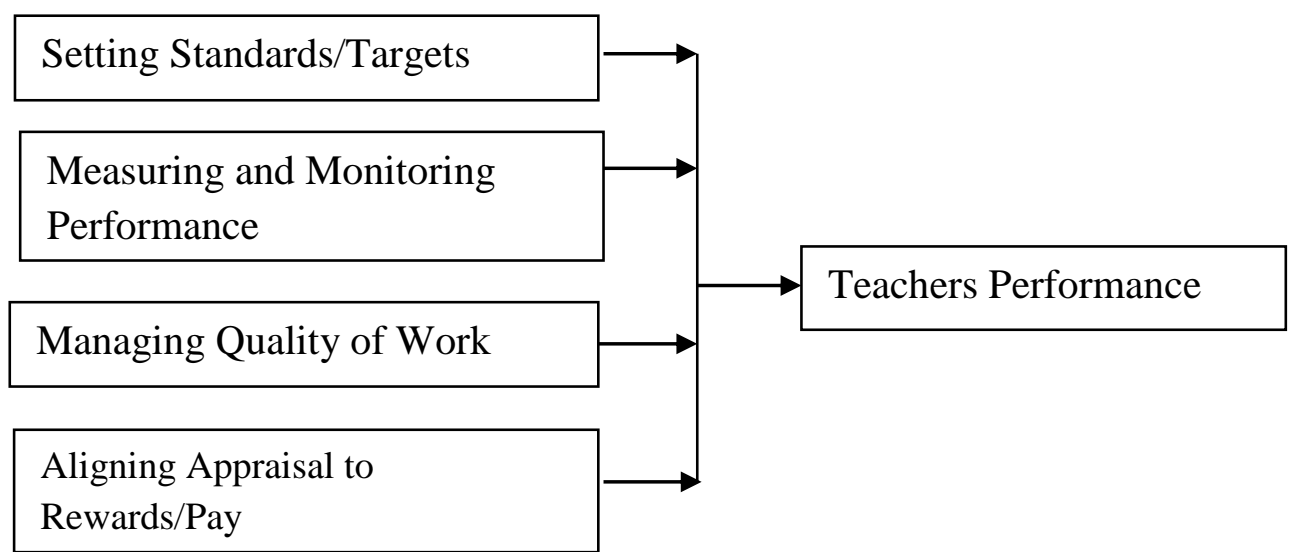

Figure 1: Conceptual Framework

Standards are a basis of comparison when measuring the extent to which various kinds of organizational performance are satisfactory or unsatisfactory. The standards/ targets need to be SMART - Specific, Measurable, Achievable, Relevant and Time Bound. This need to follow the basic control process of establishing a clear standards of performance; comparing the actual performance with the desired performance and taking a corrective action to repair the performance deficiencies. This is ensuring that employees work is able to satisfy the needs of the customers. Continuous product and service improvement need to be enhanced by ensuring that there is service delivery, better management of quality and employee participation. The performance appraisal outcomes need to be aligned to the amount of reward/pay given. Both the monetary and non monetary rewards need to be based on employees performance. Performance related rewards/pay motivate employees and improve on their productivity. Reward management is concerned about the detailing and execution of methodologies and arrangements keeping in mind the end goal to remunerate individuals decently, impartially and reliably as per their incentive to the association. It manages the improvement of remuneration methodologies and the outline, execution and support of remuneration frameworks (compensate procedures, practices and methodology) which intend to address the issues of both the association and its partners. Reward can be viewed as the major articulation of the business relationship (Armstrong, 2014). There is a direct link between rewards and motivation. Motivated employees are able to maintain their standards of living, buy goods and satisfy their wants and desires and be able to afford holidays, alleviate role stress tend to work for the organization for long. Luthans (2011) concluded that there is a big relationship between pay and job satisfaction among employees. Research has shown that employees who see a link between results as reflected in their appraisal are more likely to prepare for performance appraisal interviews, actively participate and be satisfied with the appraisal. 


\section{RESEARCH METHODOLOGY}

This study employed the use of descriptive survey research design. Descriptive survey is a method of collecting information by interviewing or administering a questionnaire to a sample of individuals (Kombo and Tromp, 2010). Kiambu county has a population of 3,479 teachers in 277 secondary schools. The subjects of the study was drawn from teachers of 22 public secondary schools in Kiambu County, where a sample of 58 teachers and 22 principals were sampled using systematic random sampling. Kothari (2011) notes that a sample of 10\% of the population is considered minimum, while $20 \%$ of the total population is required in a survey study. There are teachers from 15 public secondary schools in Kiambu County, thus 58 teachers and 22 administrators will be selected as a sample of the total population. The researcher used stematic random sampling. The population of teachers in each of the schools was taken and numbered. The researcher used sampling interval of 10 to give a sample depending on the number of teachers in the school. The head teacher was considered to be the $1^{\text {st }}$ in the sampling. The research used both primary data. Self-administered questionnaires were used. Questionnaires are considered the best in collection of primary data. This is because they provided an avenue for the researcher to ask probing questions. They are fast, cheap and can be self-administered (Mugenda \& Mugenda, 2013). Regression analysis was used to find the relationship between the dependent (target) variable and the independent variable (s) predictor variables to be able to find causal effect between them. Quantitative techniques involved the use of numerical methods to analyze data aided by MS excel package. The analyzed data was presented by use of diagrams such as pie charts and bar graphs.

\section{RESEARCH FINDINGS}

Regression analysis was used to model, examine, and explore the relationships between teacher performance and performance appraisal strategies which was operationalized as setting standards/targets, measuring and monitoring performance managing quality of work and reward/pay. This was important in measuring the extent to which changes in one or more variables jointly affected changes in another variable.

Table 1: Model Summary for performance

\begin{tabular}{|l|l|l|l|}
\hline & & & \\
& R Square & Adjusted R Square & Std. Error of the Estimate \\
\hline $.502^{\mathrm{a}}$ & .752 & .750 & 1.242 \\
\hline
\end{tabular}

The results indicate a simple correlation of $0.502 \mathrm{a}$ in the $\mathrm{R}$ column. This implies that there is a significant correlation between performance appraisal strategies and teacher performance. $\mathrm{R}$-square of 0.752 , indicates that $75.2 \%$ of the variation in teacher performance can be explained by performance appraisal parameterss. This means that performance appraisal strategies can explain $75.2 \%$ of the variability of teacher performance. 
International Journal of Current Aspects, Volume 3, Issue II, 2019, PP 218-230, ISSN 2616-6976

[IJCAB

Table 2: Analysis of Variance

\begin{tabular}{|ll|l|l|l|l|l|}
\hline \multicolumn{2}{|l|}{ Model } & Sum of Squares & df & Mean Square & F & Sig. \\
\hline $1 \quad$ & Regression & 24.453 & 4 & 6.113 & 3.962 & $.000^{\mathrm{a}}$ \\
& $\begin{array}{l}\text { Residual } \\
\text { Total }\end{array}$ & 72.527 & 71 & 1.543 & & \\
& 96.981 & 75 & & & \\
\hline
\end{tabular}

The correlation is quite significant at $\mathrm{p}<0.05$. This shows that Setting standards/target, measuring and monitoring performance, managing quality of work and Rewards/pay are one of the elements of the performance appraisal strategies that has impact on teacher performance. According to McNeal (2015) the quality and effectiveness of the teaching is the single most important factor in a child's development. It is important for the education world to see the whole picture of what an effective teacher is perceived in order to guide training, recruitment and retention.

The significance value in Table 4.10 is $0.000^{\mathrm{a}}$ which is less than 0.05 thus the model is statistically significance in predicting how various factors affect teacher performance The $\mathrm{F}$ critical at 5\% level of significance was 3.962. Since F calculated is greater than the F critical (value $=7.656)$, this shows that the overall model was significant. The relationship $(\mathrm{p}<0.05)$ indicated a linear relationship among the variables under the study meaning there was $95 \%$ chance that the relationship among the variables was not due to chance.

Table 3: Coefficients

\begin{tabular}{|c|c|c|c|c|c|c|}
\hline \multirow{2}{*}{\multicolumn{2}{|c|}{ Model }} & \multicolumn{2}{|c|}{$\begin{array}{l}\text { Unstandardized } \\
\text { Coefficients }\end{array}$} & \multirow{2}{*}{$\begin{array}{l}\text { Standardized } \\
\text { Coefficients } \\
\text { Beta } \\
\end{array}$} & \multirow[b]{2}{*}{$\mathrm{t}$} & \multirow[b]{2}{*}{ Sig. } \\
\hline & & B & Std. Error & & & \\
\hline \multirow[t]{5}{*}{1} & (Constant) & 0.531 & .809 & & 1.645 & .107 \\
\hline & Setting standards/target & .656 & .138 & 4.149 & 2.134 & .002 \\
\hline & $\begin{array}{l}\text { Measuring and } \\
\text { monitoring performance }\end{array}$ & .761 & .154 & 1.313 & 2.341 & .004 \\
\hline & $\begin{array}{l}\text { Managing quality of } \\
\text { work }\end{array}$ & .540 & .154 & 6.392 & 2.856 & .006 \\
\hline & Rewards/pay & .751 & .168 & 2.124 & 5.898 & .001 \\
\hline
\end{tabular}

a. Dependent Variable: Teacher Performance

Table 3 shows the constant in this model is represented by a value of 0.531 , which is the expected value of teacher performance when the values of the independent variables are equal to zero. Measuring and monitoring performance was found to be the most $(76.1 \%)$ 
significant among the four variables followed by rewards/pay (75.1\%), setting standards/target $(65.6 \%)$ and managing quality of work $(54.0 \%)$. Based on the analysis, the regression equation for the independent variable on the dependent variable resulted to the following; $\mathrm{Y}=0.531+0.656 \mathrm{X}_{1}+0.761 \mathrm{X}_{2}+0.540 \mathrm{X}_{3}+0.751 \mathrm{X}_{4}$. Where $\mathrm{Y}=$ Teacher Performance, $\mathrm{X}_{1}=$ Setting Standards/Targets, $\mathrm{X}_{2}=$ Measuring and Monitoring Performance, $\mathrm{X}_{3}=$ Managing Quality of Work and $\mathrm{X}_{4}=$ Rewards/Pay. As shown on Table 3, setting standards/targets, measuring and monitoring performance managing quality of work and reward/pay had a positive and significant effect on performance contracting in regulatory bodies in Kenya as indicated by beta values. The relationships $(\mathrm{p}<0.05)$ are all significant with setting standards/targets $(\mathrm{t}=2.134, \mathrm{p}<0.05)$, measuring and monitoring performance $(\mathrm{t}=2.341, \mathrm{p}<0.05)$, managing quality of work $(\mathrm{t}=2.856, \mathrm{p}<0.05)$ and reward/pay $(\mathrm{t}=5.898$, $\mathrm{p}<0.05)$. Shirley and Lixin (2007) observe that the success of Performance Contracts in such diverse countries as France, Pakistan, South Korea, Malaysia and India, has sparked a great deal of interest in this policy around the world.

\section{CONCLUSIONS}

The study concludes that setting standards and target allows schools and the teaching staff to better measure their progress helping to keep them motivated and accountable. They provide benefits in areas like planning, motivation, the attainment of rapid results and can provide a future direction for the school. The study concludes that measuring and monitoring teacher performance ensures that information is gathered so that judgments can be made and questions answered accordingly. Teacher evaluation is a vital element in improving student learning outcomes. The study concludes that teacher satisfaction and quality of work life directly affect school's ability to serve its students. Quality is critical to satisfying the performance of teacher and retaining their future loyalty. The study concludes that teachers are satisfied with the extrinsic rewards provided from the organization like: pay, bonuses, allowances. An ineffective reward management will affect teacher's satisfaction and demotivate them, hence affecting their performance outcome

\section{RECOMMENDATIONS}

The study recommends that for the management of schools to achieve goal alignment in the teaching staff, they must first clearly communicate their school's strategic objectives across the entire school. Understand more clearly all responsibilities associated with specific goals and should be measurable, specific, attainable, relevant and time bound. The process of setting standards and targets should be a collaborative process between the teaching staff and the school managers. The study recommends that the school should have a way of monitoring their teacher which must be developed in a systematic monitoring and evaluation of the class and the work of teachers. This can only be achieved through a systematic observation of teaching process as a whole. On managing the quality of work, the study recommends that schools match tasks to Skills, communicate effectively, keep goals clear \& focused, give incentives, train and develop their teachers. The study recommends that the school management should take interest in the professional growth to increase the performance level of the teachers. They also should consider the new ideas of the teachers and they should ask them the option of rewards for their motivation. 
International Journal of Current Aspects, Volume 3, Issue II, 2019, PP 218-230, ISSN 2616-6976

[JCAB

\section{REFERENCES}

Armstrong Michael (2014). Handbook of Human Resource Management Practice (13 ${ }^{\text {th }}$ Edition). London: Kogan Page Limited.

Cole G. A. (2009). Organizational Behaviour. Great Britain: DP Publications.

Dhammika, Kas. (2016). Measuring Employees Performance in the Public Sector in Sri Lanka: Testing of Two Models. Kelaniya Journal of Human Resource Management. 8. 1.10 .

Gennard, J., Judge, G., \& Gennard, J. (2010). Managing employment relations. London: Chartered Institute of Management.

KNUT Mid-Term Report for the 2016 Performance Appraisal.

Kombo, K. D. \& Tromp, A. L. (2010) Proposal and Thesis Writing. An Introduction. Nairobi. Paulines Publication Africa.

Kothari (2010). Research Methodology. Methods and Techniques (Second Edition). K. K. Gupta - New Age International Limited.

Luthans Fred (2011). Organizational Behaviour (12 ${ }^{\text {th }}$ Edition). New York: McGraw Hill International Edition.

Martin, G., Farndale E., Paume, J., and Stifles, P. (2016) Corporate governance and strategic human resource management: Four archetypes and proposals for a new approach to corporate sustainability. European Management Journal 34, 22 -35.

McNeal, M. D. (2015). Teacher Quality and Effectiveness: The Nucleus of Education.

Mugenda, O. M. \& Mugenda, A., G. (2013). Research Methods. Quantative and Qualitative Approaches. Nairobi. Acts Press.

Mullins J. Laurie (2000) Management and Organizational Behaviour ( $5^{\mathrm{TH}}$ Edition). London: Financial Times Management.

Mwema, N. W. \& Gachunga, H. G. (2014). The influence of performance appraisal on employee productivity in organizations: A case study of selected WHO offices in East Africa. International Journal of Social Sciences and Entrepreneurship, 1 (11), 324337.

Prasad L.M, 2005 "Principals and Practices of Management, Sultan Chand and Sons Publisher, New Delhi

Robbins, P., Stephen, \& Coulter Mary (2010) Management (Tenth Edition). New Jersey: Pearson Prentice Hall Limited.

Saleemi Ahmed Nisar (2010) Management. N. A. Saleemi Publishers, Nairobi, Kenya.

Teachers Service Commission Code of Regulations for Teachers, 2015. The Teacher Service Commission Act (52) (No. 20 of 2012 Kenya Gazette Supplement (No. 167).

Teachers Service Commission (2017). TSC Performance Contracting and Teachers Performance Appraisal and Development (TPAD).

Tot, D. (2014). Monitoring and Self-Evaluating Teacher's Professional Development and School Activities. Life and School: Journal of Theory and Practice of Education and Education, 60(31), 176-188.

This is an open-access article published and distributed under the terms and conditions of the $(c))_{E Y}$ Creative Commons Attribution 4.0 International License of United 
International Journal of Current Aspects, Volume 3, Issue II, 2019, PP 218-230, ISSN 2616-6976

[JCAB

States unless otherwise stated. Access, citation and distribution of this article is allowed with full recognition of the authors and the source.

Authors seeking to publish with an International Peer Reviewed Journal should consider www.ijcab.org by writing to the Editor at editor@ijcab.org. List of our Journals are Available at www.ijcab.org/journals 